\title{
Д.В. Голишкін ${ }^{1}$, Т.М. Фалалсєва ${ }^{1}$, К.С. Непорада², Т.В. Берегова ${ }^{1}$
}

\section{Вплив меланіну на стан слизової оболонки шлунка та реакцію гіпоталамо-гіпофізарно- наднирковозалозної осі за умов дії гострого стресу}

${ }^{1}$ Київський національний університет ім. Тараса Шевченка; ${ }^{2}$ Вищчий державний навчальний заклад Украӥни «Українська медична стоматологічна академія», Полтава;

E-mail:dgolyshkin@gmail.com

\begin{abstract}
Вивчали вплив меланіну дріжджеподібних грибів Nadsoniella nigra штаму X1 на концентрацію адренокортикотропного гормону (АКТГ) і кортизолу в сироватия крові щурів, а також зміни коефіцієнта маси надниркових залоз і ураження слизової оболонки шлунка (СОШ) в умовах нервово-м'язового напруження за Сельє. Введення меланіну відновлювало функиіонування гіпоталамо-гіпофізарнонаднирковозалозної осі, щчо підтверджувалося зростанням концентраиії АКТГ на $42 \%$ зниженням кортизолу на 19\% відносно 2-ї групи тварин, яким перед моделюванням стресу вводили воду. Коефіиієнти маси надниркових залоз щурів, яким вводили меланін, не відрізнялися статистично значущзо від групи контролю. Меланін зменшував площу виразкових уражень СОШ на 64\%, а також вільного оксипроліну в СОШ на 29\%, вільної фукози на 16\% і гексуронових кислот на 24\% у порівнянні з 2-ю групою щурів. Зроблено висновок, щуо в механізм стреспротективної дї меланіну залучені його вплив на виділення глюкокортикоїдів та запобігання деполімеризації колагену і сполук екстрацелюлярного матриксу СОШ. Меланін проявляє властивості гастропротектора і є перспективним засобом для профілактики та лікування наслідків дї стресу на організм.

Ключові слова: меланін; кортизол; адренокортикотропний гормон; слизова оболонка шлунка; стрес.
\end{abstract}

\section{ВСТУП}

У рамках пошуку стреспротективних сполук нами було виявлено ефективність меланіну біологічного пігменту, похідного поліфенольних сполук, отриманого з дріжджеподібних грибів Nadsoniella nigra штаму X1. Профілактичне введення меланіну попереджало виникнення уражень слизової оболонки шлунка (СОШ) щурів, викликаних методом нервовом'язового напруження за Сельє оскільки йму властива потужна антиоксидантна дія [1]. Ducrest та співавт. [2] показали, що хребетні тварини, які мають темніше забарвлення шкіри, а отже з більш інтенсивним синтезом меланіну, є стійкішими до дії стресу.

Залишаються поодинокими повідомлення щодо впливу меланіну на основні ланки стреслімітуючої системи, а також на гіпоталамо-гіпофізарно-наднирковозалозну (ГГН) вісь. С відомості що у щурів при введенні меланіну на тлі хронічного стресу вміст кортизолу зменшується [3]. Однак недослідженим залишається вплив гострого стресу на цей показник і на концентрацію адренокортикотропного гормону (АКТГ).

У засобах підтримки гомеостазу СОШ важливу роль відіграє збереження структури колагенових і неколагенових білків слизу. Біохімічною основою слизового бар'єра шлунка є протективні сполуки: нейтральні та кислі глікопротеїни, глікозаміноглікани, колагенові білки, вміст продуктів розпаду яких збільшується за умов дії стресу $[4,5]$. Враховуючи відсутність даних щодо вмісту

(C) Голишкін Д.В., Фалалєєва Т.М., Непорада К.С., Берегова Т.В. 
мукополісахаридів (за концентрацією вільної фукози та гексуронових кислот) і колагенових білків СОШ (за концентрацією оксипроліну) на тлі введення меланіну та моделювання стресових умов, вирішення цього питання заповнить одну з прогалин у вивченні механізмів антистресової дії меланіну.

Мета нашої роботи - дослідити вплив меланіну на стан СОШ щурів за розмірами виразково-ерозивних уражень, вмісту вільних протективних сполук слизу та на реакцію ендокринної системи за концентрацією АКТГ і кортизолу у наслідку дії гострого стресу.

\section{МЕТОДИКА}

Дослідження проводили на 51 самиці білого нелінійного щура, масою 120 - 150 г з дотриманням міжнародних принципів Свропейської конвенції про захист хребетних тварин, що використовуються для дослідних та інших наукових цілей [6]. Тварини були розділені на 3 групи по 17 тварин у кожній: до 1-ї ввійшли щури, яким вводили воду (контроль), до 2-ї і 3-ї щури, яким перед моделюванням стресу вводили воду і меланін (в дозі 5 мг/кг) відповідно.

Введення рідин, об'ємом 0,5 мл на щура, проводили внутрішньошлунково за 15 хв перед початком досліду. Продуцентом меланіну, використаного в наших дослідженнях, були дріжджеподібні гриби Nadsoniella nigra штаму X1, що висіяні з зразків вертикальних скель острова Галіндез (Українська Антарктична станція “Академік Вернадський”). Стресові ураження викликали методом нервово-м'язового напруження за Сельє. Цей метод рекомендований Державним фармакологічним центром України при проведенні доклінічних досліджень стреспротекторної дії фармакологічних засобів [7]. Така модель стресу є найбільш наближеною до природних умов, бо поєднує в собі елементи емоційного та фізичного навантаження [8]. Щурів іммобілізували протягом 3 год на операційному столику на спині, атравматично фіксуючи за кінцівки. Через 2 год після припинення знерухомлення їх умертвляли за допомогою цервікальної транслокації, діставали та зважували надниркові залози. Коефіцієнт маси надниркових залоз обчислювали за формулою: КМ = маса органа (мг) / маса тіла тварини (г) • 100 [7]. Виймали шлунок, розрізали по малій кривизні, вивертали слизовою назовні та промивали. СОШ аналізували на гастроскопі при трансілюмінаційному освітленні за допомогою лупи (збільшення у 4 рази). Диференційно підраховували площу виразок і довжину ерозій. 3 серцевої сумки збирали кров в пробірки, центрифугували 20 хв при $+4{ }^{\circ} \mathrm{C}(2200 \mathrm{~g})$ та відбирали сироватку. Визначали вміст АКТГ та кортизолу у сироватці крові щурів методом імуноферментного аналізу за допомогою комерційних наборів виробництва “DRG International Inc.” (США) та ТОВ НВЛ «Гранум» (Україна) відповідно. Усі зразки були проаналізовані в двох повторах.

У гомогенаті СОШ визначали вміст вільних оксипроліну [9], фукози [10] і гексуронових кислот [11] за стандартними біохімічними методиками.

Одержані результати перевіряли на нормальність розподілу за допомогою $\mathrm{W}$ тесту Шапіро-Уілка. Оскільки наші результати виявилися нормально розподілені, порівняння вибірок проводили за допомогою критерію $\mathrm{t}$ Стьюдента для незалежних вибірок. Розраховували середнє значення (M), похибку середнього значення (m). Значущими вважали відмінності при $\mathrm{P} \leq 0,05$.

\section{РЕЗУЛЬТАТИ ТА ЇХ ОБГОВОРЕННЯ}

Встановлено, що в сироватці крові щурів 1-ї групи концентрація АКТГ і кортизолу стано-

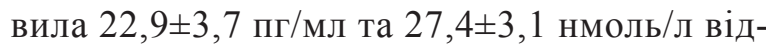
повідно. У щурів 2-ї групи, через 2 год після дії стресу, концентрація АКТГ зменшилася відносно групи контролю на 56\% $(\mathrm{P}<0,01)$, а кортизолу зросла на $320 \%(\mathrm{P}<0,001)$, що зумовлено відомим негативним зворотним зв'язком між концентрацією кортизолу в 
крові і рівнем секреції АКТГ гіпофізом. Введення щурам меланіну перед нанесенням стресу викликало підвищення концентрації АКТГ на $42 \%(\mathrm{P}<0,05)$ та одночасне зниження кортизолу на $19 \%(\mathrm{P}<0,05)$ відносно значень 2-ї групи (рис. 1, 2). Описане зростання концентрації АКТГ пов'язано зі зменшенням зворотного інгібування його секреції при зниженні концентрації кортизолу.

Одержані результати узгоджуються 3 даними Чижанської та співавт. [3], які досліджували адаптогенний вплив меланіну за умов дії хронічного стресу у щурів. Вони показали, що концентрація кортизолу у тварин, яким перед початком досліду вводили пігмент істотно зменшувалася відносно значень у тварин, яким вводили воду.

Таким чином, одним 3 механізмів антистресової дії меланіну є його вплив на гіпофізарно-наднирковозалозну вісь, що призводить до зниження концентрації кортизолу в крові. Одержані результати підтверджені нашими наступними дослідженнями, в яких ми вивчали коефіцієнти маси надниркових залоз. Встановлено, що у щурів 1-ї групи коефіцієнти маси лівої та правої надниркових залоз становили $11,8 \pm 0,5$ та $14,3 \pm 0,7$ відповідно. У щурів 2-ї групи ці показники зростали на $53(18 \pm 0,7, \mathrm{P}<0,001)$ та $42 \%$

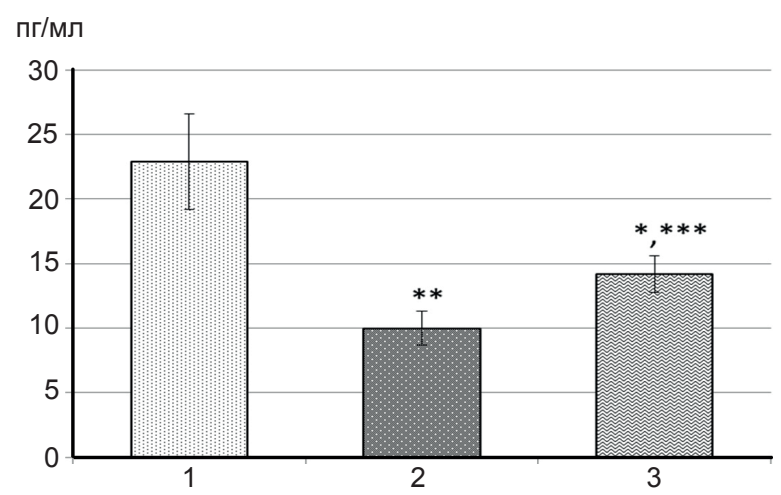

Рис. 1. Концентрація адренокортикотропного гормону в плазмі крові щурів після дії нервово-м' язового напруження, за умов профілактичного введення меланіну в дозі 5 мг/кг: 1-контроль, 2-стрес, 3-стрес і меланін (n=7).

* $\mathrm{P}<0,05, * * \mathrm{P}<0,01$ у порівнянні $з$ контролем; *** $\mathrm{P}<0,05$ у порівнянні з групою щурів, підданих дії стресу

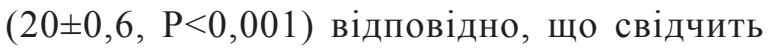
про гіпертрофію надниркових залоз, яка $\epsilon$ результатом підвищеного синтезу та секреції кортикостероїдів, в т.ч. кортизолу. Коефіцієнти маси лівої та правої надниркових залоз щурів, яким перед моделюванням стресу вводили меланін, статистично значущо не відрізнялися від контролю, що підтверджує виражену стреспротективну активність меланіну (рис. 3).

Раніше нами було встановлено, що профілактичне введення меланіну зменшує інтенсивність перекисного окиснення ліпідів у СОШ щурів [1]. Відомо, що активні форми кисню (АФК) посилюють виділення прозапальних цитокінів. Так, показано, що АФК можуть підвищувати вміст фактора некрозу пухлин $\alpha$ (TNF- $\alpha)$ в альвеолярних макрофагах мишей в умовах отруєння кремнеземом, що ще більше посилює оксидативний стрес [12]. Зростання інтенсивності запальних процесів за умов виділення прозапальних цитокінів зумовлює активацію осі ГГН [13]. Надмірна кількість кортикостероїдів порушує процеси мікроциркуляції в СОШ, погіршує продукцію слизу, що в свою чергу зумовлює збільшення ураженості в шлунку [14]. Профілактичне введення меланіну зменшує утворення АФК, що відповідно пом’якшує перебіг запального

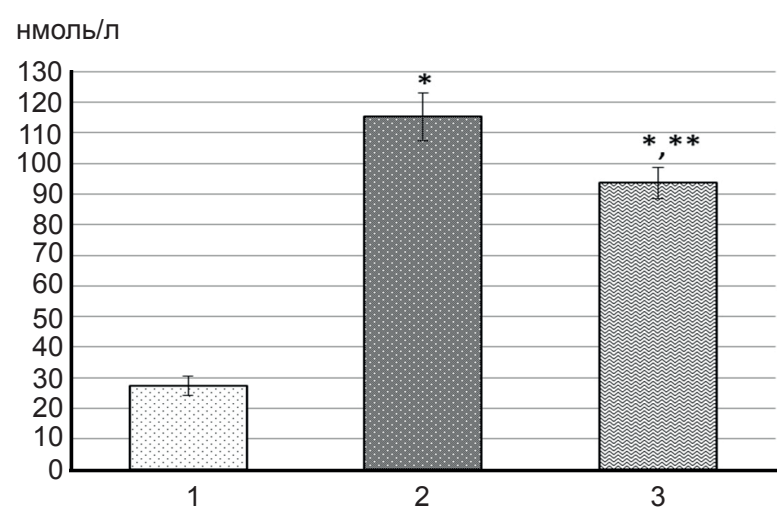

Рис. 2. Концентрація кортизолу в плазмі крові щурів після дії нервово-м'язового напруження, за умов профілактичного введення меланіну в дозі 5 мг/кг: 1-контроль, 2-стрес, 3-стрес і меланін ( $\mathrm{n}=7)$.

* $\mathrm{P}<0,001$ у порівнянні $з$ контролем, ** $\mathrm{P}<0,05$ у порівнянні з групою щурів, підданих дії стресу 


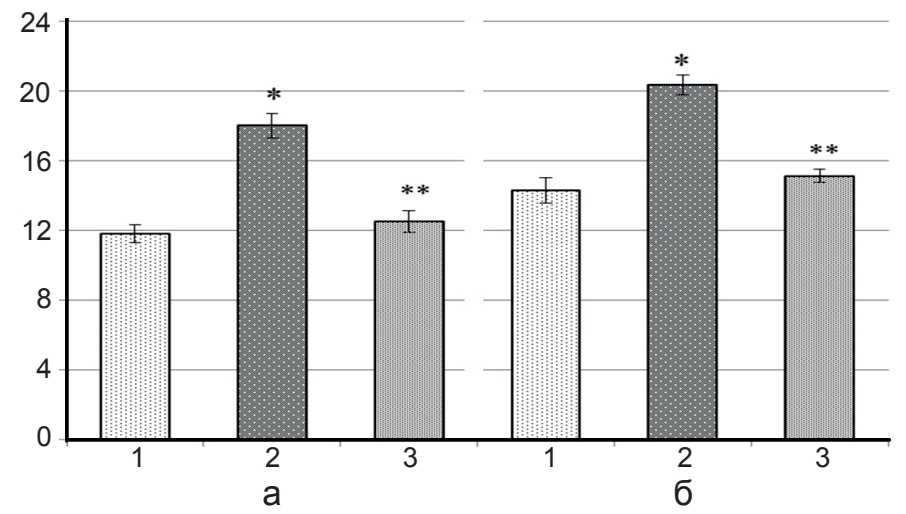

Рис. 3. Коефіцієнт маси лівої (а) та правої (б) надниркової залози після дії нервово-м'язового напруження, за умов профілактичного введення меланіну в дозі 5 мг/кг: 1-контроль, 2-стрес, 3-стрес і меланін $(\mathrm{n}=10)$.

* $\mathrm{P}<0,001$ у порівнянні з контролем, ** $\mathrm{P}<0,001$ у порівнянні з групою щурів, підданих дії стресу

процесу і призводить до зменшення виділення кортикостероїдів. Таким чином уражуючий вплив стресу на СОШ зменшується.

Слід відмітити, що після моделювання стресу в СОШ щурів контрольної групи розвивались виразки та ерозії, площа та довжина яких відповідно становили 9,5 $\pm 2,4$ мм $^{2}$ та $14,5 \pm 2,4$ мм із розрахунку на один шлунок. У групі щурів, яким до початку дії стресу вводили меланін, ураженість була значно меншою. Меланін на $64 \%(\mathrm{P}<0,05)$ зменшував площу виразок (рис. 4). При зменшенні довжини ерозій не спостерігалося статистично значущих змін. Отримані результати дають змогу розглянути меланін як адаптоген природного походження, що має цитопротекторний вплив, зменшуючи концентрацію глюкокортикоїдів у крові до значень, у яких вони чинять протективну дію [15].

Стабільність та відновлення слизового бар'єру забезпечується підтримкою нервово-трофічного постачання його структур. Цей процес характеризується надходженням поживних речовин, кисню та утилізацією таких продуктів обміну, як вуглекислий газ, вільнорадикальні сполуки тощо. Емоційно-фізичне навантаження провокує дезінтеграцію вегетативної нервової системи, що є причиною підвищення секреції шлункового соку та тривалого спазму судин шлунка. Локальне сповільнення кровопостачання зу- мовлює ішемію відповідних ділянок шлунка. За умов ішемії спостерігається накопичення пуринів, лактату, двоокису вуглецю та інших метаболітів на фоні зниження концентрації кисню в тканині [16]. Відновлення циркуляції крові за допомогою компенсаторних механізмів, як наприклад активація ендотеліальної синтази оксиду азоту, призводить до реперфузійної гіперемії. Клітини усіх шарів стінки шлунка, у тому числі слизового бар'єру, за умов гіперемії, після кисневого голодання, активно споживають кисень, генеруючи перекисні сполуки, що призводить до ураження клітинних мембран та вільнорадикального ульцерогенезу [16].

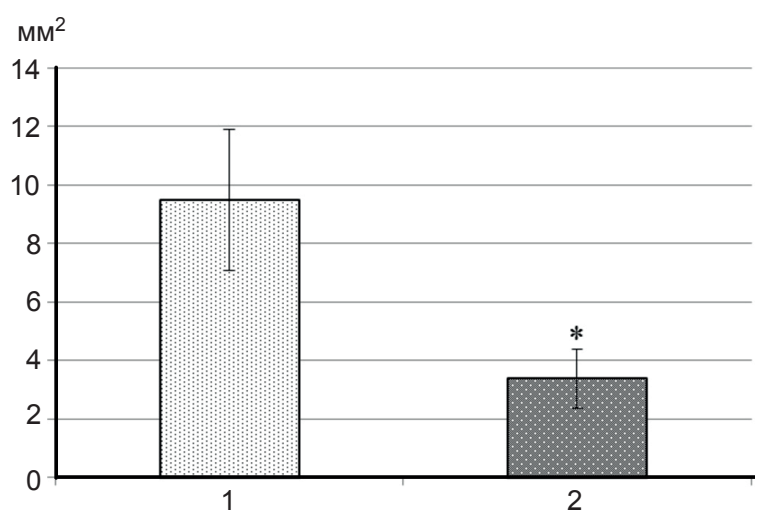

Рис. 4. Площа виразок у слизовій оболонці шлунка щурів після дії нервово-м'язового напруження, за умов профілактичного введення меланіну в дозі 5 мг/кг:1- стрес, 2- стрес і меланін $(\mathrm{n}=10)$.

* $\mathrm{P}<0,05$ у порівнянні з групою щурів, підданих дії стресу 
Під час запального процесу у зоні ураження СОШ підвищується синтез фактора росту фібробластів (FGF-2), інсуліноподібного фактора росту (IGF-1), а також трансформуючого фактора росту $\beta$ (TGF- $\beta$ ). Вони активують трансформацію фібробластів сполучної тканини у міофібробласти, сприяють ангіогенезу та наступному реепітелізаційному процесу [17]. Під контролем цитокінсигнальної системи (TGF- $\beta$ ) фібробластами сполучної тканини шлунка синтезуються колаген та сполуки екстрацелюлярного матриксу (ЕЦМ - фібронектин, глікозаміноглікани, протеоглікани та гіалуронова кислота). Це основні компоненти, необхідні для відновлення уражених ділянок СОШ за допомогою формування нового сполучнотканинного матриксу для стягування країв виразково-ерозивних уражень та забезпечення основи для міжклітинної адгезії, росту та диференціації клітин. Активація імунної відповіді й запального процесу збільшує системний вміст глюкокортикоїдів, що за умов їх надмірного впливу призводить до зниження синтезу цитокінів, мембранних ліпідів та простагландинів [17]. Це зумовлює зниження утворення колагену та сполук ЕЦМ, тоді як їх наявність в СОШ у вільній формі може вказувати на патологічні зміни слизової оболонки, що супроводжуються руйнуванням сполучної тканини. При цьому ускладнюється процес відновлення слизового бар'єру та рубцювання виразкових уражень. За таких умов відбувається руйнування СОШ, що виявляється у зростанні концентрації вільного оксипроліну, фукози та гексуронових кислот [4,5].

Тому наступним етапом нашої роботи було дослідити вплив меланіну на стан слизово-епітеліального бар'єру. Встановлено, що після дії стресу в тканині СОШ вміст вільного оксипроліну зростав на 73,2\% $(\mathrm{P}<0,001)$ порівняно $з$ групою контролю, що свідчить про активацію колагенолітичних процесів (таблиця). При введенні меланіну вміст вільного оксипроліну в СОШ значущо знижувався на $29 \%$ ( $<<0,001)$ порівняно 3 2-ю групою щурів. Hasebe та співавт. [4] показали важливість оксипроліну як одного 3 основних маркерів ульцерогенезу за умов водно-іммобілізаційного стресу. Тоді як інші автори [18] відмічають необхідність колагену у клітинній диференціації та швидкості гоєння виразкових уражень при етаноліндукованому ульцерогенезі. Отже, меланін може виступати важливим елементом захисту структурної цілісності СОШ за умов дії стресу різного генезу.

Сполуки ЕЦМ також є місцем прикріплення шлункового патогена Helicobacter pylori. Зазначена взаємодія можлива через Lewis ${ }^{\mathrm{b}}$-антиген, фукозильований глікан, що містить $\alpha(1,2)$-та $\alpha(1,4)$-зв'язану фукозу. Фукоза - структурний моносахарид СОШ, що бере участь у лейкоцит-ендотеліальній адгезії, взаємодії хазяїн-мікроб та міжклітинній взаємодії через Notch-сигнальну систему [19]. Показано, що H. pylori проявляє властивості молекулярної мімікрії, тобто здатна до продукування Lewis ${ }^{\mathrm{b}}$-подібних структур хазяїна таких, як Lewis ${ }^{x}$, Lewis ${ }^{\mathrm{s}}$ та Lewis ${ }^{\mathrm{b}}$. Експресія вищезазначених фукозильованих гліканів H. pylori може індукувати ураження шлункового епітелію, що призводить до атрофічного гастриту у людей інфікованих ним [19]. Отже, ідентифікація підвищеного вмісту фукози у СОШ може слугувати маркером іiі ураження. Показано, що гострий стрес призводив до збільшення вмісту вільної фукози в слизовому бар'єрі на 55\% $(\mathrm{P}<0,001)$ порівняно $з$ інтактними тваринами. Після введення меланіну, відмічалося статистично значуще зменшення цього компонента в пристінковому слизі на $16 \%(\mathrm{P}<0,001)$ порівняно 32 -ю групою щурів (див. таблицю). Таким чином, меланін запобігає деградації фукопротеїнів сполучної тканини слизово-епітеліального бар'єру шлунка за умов дії стресу.

Також після нервово-м'язового напруження вміст вільних гексуронових кислот у пристінковому слизі шлунка збільшувався на 75\% $(\mathrm{P}<0,001)$ порівняно 3 групою контролю. При профілактичному введенні меланіну цей показник зменшувався на 24\% ( $<0,001)$ порівняно 3 щурами, яким вводили воду (див. таблицю). 
Вміст продуктів деградації захисних сполук (мкмоль/г) у пристінковому слизі шлунка щурів після дії нервовом'язового напруження, за умов профілактичного введення меланіну в дозі 5 мг/кг $(\mathrm{M} \pm \mathbf{m}, \mathbf{n = 1 0})$

\begin{tabular}{l|c|c|c|}
\hline Показник & Контроль & Стресс & Стрес і меланін \\
\hline Оксипролін & $1,98 \pm 0,07$ & $3,43 \pm 0,14^{*}$ & $2,44 \pm 0,08^{*}, * *$ \\
Фукоза & $5,27 \pm 0,27$ & $8,14 \pm 0,13^{*}$ & $6,81 \pm 0,26^{*}, * *$ \\
Гексуронові кислоти & $0,75 \pm 0,04$ & $1,31 \pm 0,04 *$ & $0,99 \pm 0,05^{*}, *$ \\
\hline
\end{tabular}

* $\mathrm{P}<0,001$ у порівнянні з контролем; ** $\mathrm{P}<0,001$ у порівнянні з групою щурів, підданих дії стресу

Наші результати свідчать, що меланін ефективно захищає СОШ від деградації глікозаміногліканів.

Отже, профілактичне введення меланіну попереджувало деполімеризацію колагену та сполук ЕЦМ шлунку, свідченням чого $\epsilon$ зменшення відповідно концентрації вільного оксипроліну, фукози та гексуронових кислот. При цьому цілісність слизового бар'єру була наближеною до значень контрольних щурів, що узгоджується 3 результатами макроскопічного аналізу СОШ. Отримані результати свідчать, що одним з механізмів гастропротекторної дії меланіну є його проникнення через центральну гідрофобну зону клітинних мембран та реалізацію антиоксидантної дії. Такий механізм був запропонований на основі попередньо отриманих змін вольт-амперних характеристик модельних бімолекулярних ліпідних мембран (БЛМ) за умов збільшення концентрації меланіну у навколомембранному розчині. Так, нами було встановлено, що при збільшенні концентрації меланіну в діапазоні $10^{-9}-10^{-6}$ моль/л підвищувалася питома провідності ліпідного бішару та зменшувалася його ємність. Подальше збільшення концентрації меланіну в діапазоні $10^{-6}-10^{-5}$ моль/л характеризувалося зменшенням питомої провідності та стабілізуванням електричної ємності БЛМ [20]. Такий ефект можна пов'язати з можливістю накопичення в об'ємі мембрани меланіну для формування додаткового структурного та антиоксидантного бар'єру СОШ.

\section{ВИСНОВКИ}

1. Меланін запобігає гіперактивації гіпоталамо-гіпофізарно-наднирковозалозної осі за умов дії стресу, що підтверджувалося відновленням вмісту кортизолу і адренокортикотропного гормону та зменшенням коефіцієнта маси надниркових залоз.

2. Введення меланіну захищає слизову оболонку шлунка щурів від виразкових уражень, викликаних методом нервово-м'язового напруження за Сельє.

3. Профілактичне введення меланіну попереджає деполімеризацію колагену та сполук екстрацелюлярного матриксу шлунку, свідченням чого є зменшення відповідно концентрації вільного оксипроліну, вільної фукози та гексуронових кислот.

4. Меланін проявляє властивості гастропротектора і є перспективним засобом для профілактики та лікування наслідків дії стресу на організм.

Робота виконана за підтримки та на замовлення Держінформнауки ДУ «Національний антарктичний науковий иентр» Міністерства освіти і науки Украӥни №H/6-2012 (12ДФ036-08) від 01 серпня 2012 р. «Визначення механізму профілактично-лікувальної дії біологічно активних речовин, виділених з антарктичних організмів». Державний реєстраційний номер 0112 U004870.

\section{Д.В. Голышкин ${ }^{1}$, Т.М. Фалалеева ${ }^{1}$, К.С. Непорада ${ }^{2}$, Т.В. Береговая ${ }^{1}$ \\ ВЛИЯНИЕ МЕЛАНИНА НА СОСТОЯНИЕ СЛИЗИСТОЙ ОБОЛОЧКИ ЖЕЛУДКА И РЕАКЦИЮ ГИПОТАЛАМО-ГИПОФИЗАР- НО-НАДПОЧЕЧНИКОВОЙ ОСИ В УСЛОВИЯХ ОСТРОГО СТРЕССА}

Изучали влияние меланина дрожжеподобных грибов Nadsoniella nigra штамма X1 на концентрацию адрено- 
Голишкін Д.В., Фалалєєва Т.М., Непорада К.С., Берегова Т.В.

кортикотропного гормона (АКТГ) и кортизола в сыворотке крови крыс, а также изменения коэффициента массы надпочечников и поражение слизистой оболочки желудка (СОЖ) в условиях нервно-мышечного напряжения по Селье. Введение меланина восстанавливало функционирование гипоталамо-гипофизарно-надпочечниковой оси, что подтверждалось ростом концентрации АКТГ на $42 \%$ и снижением кортизола на 19\% относительно 2-й группы животных, которым перед моделированием стресса вводили воду. Коэффициенты массы надпочечников крыс, которым вводили меланин, не отличались статистически значимо от контроля. Меланин уменьшал площадь язвенных поражений СОЖ на 64\%, а также снижал содержание свободного оксипролина в СОЖ на 29\%, свободной фукозы на $16 \%$ и гексуроновых кислот на $24 \%$ в сравнении с 2-й группой крыс. Сделано вывод, что в механизм стреспротективного действия меланина вовлечены его влияние на выделение глюкокортикоидов и предотвращение деполимеризации коллагена и соединений екстрацелюлярного матрикса СОШ. Меланин проявляет свойства гастропротектора и является перспективным средством для профилактики и лечения последствий воздействия стресса на организм. Ключевые слова: меланин; кортизол; адренокортикотропный гормон; слизистая оболочка желудка; стресс.

\section{Golyshkin D.V. ${ }^{1}$, Falalyeyeva T.M. ${ }^{1}$, Neporada K.S. ${ }^{2}$, Beregova T.V. ${ }^{1}$ \\ THE INFLUENCE OF MELANIN ON THE GASTRIC MUCOSA AND HYPOTHALAMIC- PITUITARY-ADRENOCORTICAL AXIS UNDER ACUTE STRESS CONDITIONS}

We studied the influence of melanin from yeast-like fungi Nadsoniella nigra strain $\mathrm{X} 1$ on the changes of the levels of adrenocorticotropic hormone (ACTH) and cortisol in blood serum of rats, adrenal glands weight ratio and lesions of the gastric mucosa (GM) caused by neuromuscular tension by Selye. Melanin administration restored functioning of the hypothalamic-pituitary-adrenal axis that was evident by an increase of ACTH concentration by $42 \%$ and a decrease of cortisol concentration by $19 \%$ compared to the rats injected with water (group 2). In rats treated with melanin, the adrenal glands weight ratio, didn't differ from intact control group of the rats. Melanin decreased ulcers area by $64 \%$ and reduced the content of free hydroxyproline by $29 \%$, the free fucose by $16 \%$ and the free hexuronic acids by $24 \%$ in the GM compared to the group 2 of the rats. It is established that the mechanism of melanin stress-protective properties are based on its regulation of the glucocorticoids secretion and prevention of GM collagen and extracellular matrix substances depolymerization. Melanin possesses gastroprotective properties and is a perspective agent for preventing and treatment of consequences of the stress influence on the organism.

Key words: melanin; cortisol; adrenocorticotropic hormone; gastric mucosa; stress.
${ }^{1}$ ESC "Institute of Biology" of Taras Shevchenko National University, Kyiv

${ }^{2}$ Higher medical educational institution of Ukraine

"Ukrainian Medical Stomatological Academy", Poltava

\section{REFERENCES}

1. Golyshkin D, Savytskyy Ya., Falalyeyeva T. Influence of melanin on the lesion in the gastric mucosa of rats caused by neuro-muscular tension according to Selye. Annales universitatis Mariae Curie - Sklodowska. 2010; (2):251-5.

2. Ducrest AL, Keller L, Roulin A. Pleiotropy in the melanocortin system, coloration and behavioural syndromes. Trends Ecol Evol. 2008; 23(9):502-10.

3. Chyzhanska NV. Influence of the malanin on cortisol level in rats blood before and after the stress. Bulletin of biology and medicine problems. 2007; (1):40-4. [Ukrainian]

4. Hasebe T. Collagen and collagenase in ulcer tissue-2. Restraint and water immersion induced gastric lesions and effects of cimetidine and misoprostol. Tokai J Exp Clin Med 1987; 12(3):181-90.

5. Skrypnyk IM. Biochemical mechanism of ulcer development under stressful conditions. Ukr. Biokhim. Zh. 2001; 73(1):110-4. [Ukrainian]

6. Rozemond H. Laboratory animal protection: the European Convention and the Dutch Act. Vet Q. 1986; 8(4):346-9.

7. Stefanova OV. Preclinical studies of drugs: guidance. Kyiv: Avicena; 2001. [Ukrainian]

8. Ader R. Psychoneuroimmunology. San Diego: Cohen Academic Press; 2001.

9. Tetyanets SS. Method for determination of free oxyproline in serum. Lab delo. 1985; (1) :61-2. [Russian]

10. Sharaev PN, Strelkov NS, Kildiyarova RR. Method for determination of fucose is not bound to proteins. Clin lab diagnostica. 1997; (4):17-8. [Russian]

11. Sharaev PN. Method for determination of glycosaminoglycans in biological fluids. Lab delo.1987; (5):530-2. [Russian]

12. Barrett EG, Johnston C, Oberdorster G, Finkelstein JN. Antioxidant treatment attenuates cytokine and chemokine levels in murine macrophages following silica exposure. Toxicol Appl Pharmacol. 1999; 158 (3):211-20.

13. Sapolsky R, Rivier C, Yamamoto G. et al. Interleukin-1 stimulates the secretion of hypothalamic corticotropinreleasing factor. Science. 1987 Oct 23; 238 (4826):522-4.

14. Dekanski JB, Macdonald A, Sacra P. Effects of fasting, stress and drugs on gastric glycoprotein synthesis in the rat. Br J Pharmacol. 1975; 55 (3):387-92.

15. Filaretova L. Glucocorticoids are Gastroprotective under Physiologic Conditions. Ther Adv Chronic Dis. 2011; 2(5):333-42.

16. Schirmer CM, Kornbluth J, Heilman CB, Bhardwaj A. Gastrointestinal prophylaxis in neurocritical care. Neurocrit Care. 2012 ;16(1):184-93.

17. Reinke JM, Sorg H. Wound repair and regeneration. Eur 
Surg Res. 2012;49(1):35-43.

18. Arisawa T, Shibata T, Kamiya Y., et al. Effects of sucralfate, cimetidine and rabeprazole on mucosal hydroxyproline content in healing of ethanol-hcl-induced gastric lesions. Clin Exp Pharmacol Physiol. 2006;33(7):628-32.

19. Becker DJ, Lowe JB. Fucose: biosynthesis and biological function in mammals. Glycobiology. 2003;13(7):41-53.

20. Golyshkin D, Rybalchenko V, Bychko A, Beregova T, Falalyeyeva T. Influence of melanin on electrical characteristics of model bilipid membranes (in vitro). Bulletin of Taras Shevchenko national university of Kyiv. 2014; 66(1): 90-2. [Ukrainian]. 